\title{
D Vitamini ve İn Vitro Fertilizasyon Sonuçları Üzerine Bir Derleme
}

\section{A Review on the Vitamin D and In Vitro Fertilization Outcomes}

\author{
İlkay $\mathrm{BOZ}^{\mathrm{a}}$ iD Gamze TESKERECİ ${ }^{\mathrm{b}}$ iD
}

ÖZET D vitamininin kalsiyum-fosfor dengesinin sürdürülmesi ve kemik mineralizasyonundaki fonksiyonu oldukça iyi bilinse de üremeye etkisi tartışmalı bir konudur. Ulusal ve uluslararası çalışmalarda D vitamini eksikliğinin üreme çağındaki kadınlarda oldukça yaygın olduğu görülmektedir. D vitamininin seks steroid hormonlarıyla birlikte, kadın ve erkek üreme süreçlerinde etkili olduğu bilinmektedir. D vitamini reseptörlerinin ve vitamini metabolize eden enzimlerin üreme organlarında bulunması bu görüşü desteklemektedir. D vitamini eksikliği; infertilitenin etiyolojik faktörleri olan miyom, endometriozis, polikistik over, düşük ovarian reservi, düşük total sperm sayısı ve testesteron düzeyi ile ilişkilendirilmektedir. D vitamini eksikliğinin In Vitro Fertilizasyon sonuçları üzerinde etkilerini inceleyen 13 çalışmaya ulaşılmıştır. Ülkemizde bu konuda yapılan bir çalışmaya ulaşılmamıştır. Ayrıca bu alanda yapılmış iki adet sistematik derleme bulunmaktadır. Ancak tedavi öncesi rutin D vitamini takibi ve eksikliğine ilişkin tedavi ve bakımın yaygınlaştırılması için büyük ölçekli, kohort ve deneysel çalışmalara gereksinim vardır.

Anahtar Kelimeler: D vitamini, infertilite, In Vitro Fertilizasyon, gebelik sonucu

\begin{abstract}
The effect on reproductive process of vitamin D is a controversial issue although the function on the bone mineralization and maintaining of the calcium-phosphorus balance of vitamin D is quite well-known. National and international studies show that vitamin D deficiency is quite common among women of reproductive age. Vitamin D with sex steroids are known to be effective in male and female reproductive processes. It supports the view that the presence of the reproductive tissue of Vitamin D receptors and enzymes that metabolize Vitamin D. In the literature, Vitamin D deficiency is associated with etiologic factors of infertility such as fibroids, endometriosis, polycystic ovary syndrome, low ovarian reserve, lower total sperm counts and testosterone levels. In this review, 13 research were achieved examining the impact on In Vitro Fertilization results of Vitamin D. In our country, it could not be reached to a study in this issue. Also, there are two systematic review in this issue. To routine monitoring of vitamin $\mathrm{D}$ and promoting of treatment and care in the lack of Vitamin D, large-scale, experimental and cohort studies are needed.
\end{abstract}

Key words: Vitamin D, infertility, In Vitro Fertilization, pregnancy outcome

\section{Giris}

Geleneksel olarak D vitamininin kemik metabolizmas1 ve kalsiyum-fosfor dengesi üzerine rolleri olduğu bilinmektedir. ${ }^{1,2}$ Son y1llardaki pek çok invitro ve invivo çalışma D vitamininin non-kalsemik rollerinin olduğunu ortaya çıkartmıştır. ${ }^{3-7}$ Dahası çalışmalar D vitamini eksikliğinin jinekolojik ve obstetrik hastalıkların gelişiminde rol oynayabileceğini de göstermektedir. ${ }^{8,9}$ Özellikle D vitamininin üreme sağlığ1 ve infertilite alanındaki etkileri yakından incelenmektedir. ${ }^{10}$

Bilindiği üzere, D vitamininin \%8090'1 güneş 1şı̆̆ııın etkisiyle ciltte üretilirken, geri kalanı beslenme yoluyla elde edilmektedir. ${ }^{11,12}$
D vitamininin ultraviyole 1şınlarıyla deride sentezlenen kolekalsiferol (Vitamin D3) ve başlıca balık, süt ürünleri ve yumurta olmak üzere besinlerle alınan ergokalsiferol (Vitamin D2) olmak üzere iki temel kaynağı vardır. D2 ve D3 vitaminlerinin her ikisi de ayn 1 yolla metabolize olduğundan ortak bir isimle D vitamini olarak adlandırılmaktadır. ${ }^{11}$ Ciltten ve beslenmeden gelen D vitamini, 25 hidroxylase enzimi ile $25(\mathrm{OH}) \mathrm{D}$ 'ye karaciğerde metabolize edilmek-tedir. D vitamininin sentezi tamamlandıktan sonra hedef hücrelerde fonksiyon görmektedir. D vitamininin sentezi ile gebelik ve üreme üzerine dolaylı etkisi Şekil 1'de özetlenmiştir.

Geliş Tarihi/Received: 02-01-2017 / Kabul Tarihi/Accepted 24-08-2017

a Yrd. Doç. Dr. ̇̇lkay BOZ, Doğum ve Kadın Hastalıkları Hemşireliği Anabilim Dalı Öğretim Üyesi, Akdeniz Üniversitesi, Hemşirelik Fakültesi, 07058 Kampüs, Antalya/TÜRKIYE, E-Posta : ilkayarslan@akdeniz.edu.tr; ORCID ID: 0000-0002-3529-9351

b Dr. Gamze TESKERECİ, e-Posta: gteskereci@gmail.com, ORCID ID: 0000-0003-0298-9716

Sorumlu yazar /Correspondence: Dr. Gamze TESKERECI, gteskereci@ gmail.com 


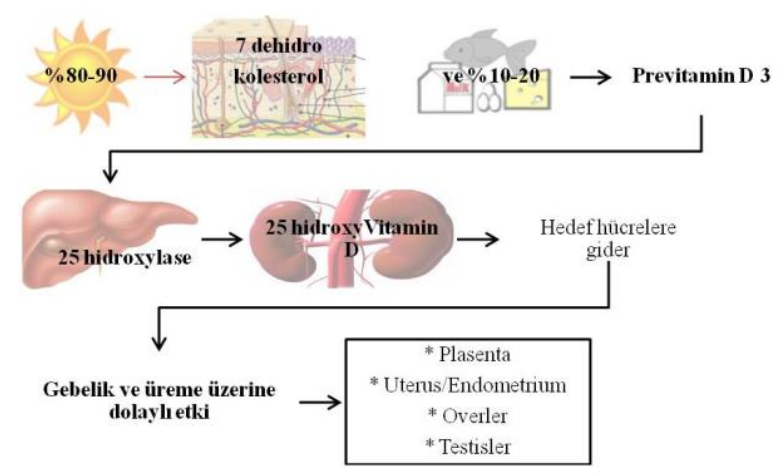

Şekil 1. D Vitamininin Sentezinin Üreme ve Gebelik Üzerine Etkisi

\section{Vitamini Eksikliğinin İnfertilite Etiyolojik Faktörleriyle İlişkisi}

D vitamini eksikliğinin infertilitenin etiyolojik faktörleri arasinda yer alan endometriozis ${ }^{13-16}$, polikistik over ${ }^{17-20}$, uterin fibroidler ${ }^{21-23}$, semen kalitesi $^{24,25}$ ve testesteron düzeyi ${ }^{26,27}$ ile ilişkili olduğu çalışmalarla ortaya çıkartılmıştır. Ayrıca ovarian yetmezlik ile D vitamini ilişkisini kanıtlayan çalışmalara ulaşılmaktadır. $\mathrm{Bu}$ çalışmalardan birinde ovarian foliküler sıvıdaki $\mathrm{D}$ vitamini düzeyinin anti-mülerian hormon salınımı ile pozitif ilişkide olduğu ve $D$ vitamini düzeyinin ovarian sağlı için önemli hücrelerden biri olan human granül hücreleri etkileyebileceği, böylece üreme üzerinde etkili olduğu saptanmıştır. ${ }^{28}$ Abdul-Rasheed ve ark. ${ }^{29}$, $\mathrm{D}$ vitamini düzeyi ile anti-mülerian hormon arasındaki ilișkiyi incelediklerinde, infertil grupta D vitamini düzeyinin $(35.38 \pm 5.83 \mathrm{ng} /$ $\mathrm{mL})$, fertil olan kontrol gruba $(49.99 \pm 12.90 \mathrm{ng} /$ $\mathrm{mL}$ ) göre anlamlı düzeyde düşük olduğunu saptamıştır. Ayrıca aynı çalışmada D vitamini düzeyi arttıkça, anti-mülerian hormon düzeyinin arttığı, beden kitle indeksi arttı̆̆ında anti-mülerian hormon düzeyinin azaldığ1 bulunmuştur. Türkiye'den Konya'da 63 kadınla yapılan bir vaka-kontrol çalışmasında primer ovarian yetmezliği olan kadınlarda $\mathrm{D}$ vitamini eksikliği, sağlıklı kadınlara göre daha yüksek bulunmuştur. $^{30}$

\section{İnfertilite Tedavisi Gören Kadınlarda D Vitamini Düzeyi \\ D vitaminin değerlendirilmesinde kanda} 25(OH)D seviyesi dikkate alınmaktadır. Değerlendirmede $25(\mathrm{OH}) \mathrm{D}$ seviyesi $30-80$ $\mathrm{ng} / \mathrm{mL}$ arasında ise $\mathrm{D}$ vitamini düzeyi yeterli; $20-29 \mathrm{ng} / \mathrm{ml}$ ise $\mathrm{D}$ vitamini düzeyi yetersiz; $<20$ $\mathrm{ng} / \mathrm{ml}$ ise $\mathrm{D}$ vitamini düzeyi düşük olarak tanımlanmaktadır. ${ }^{11,31}$ İnfertilite tedavisi gören kadınlarda $\mathrm{D}$ vitamini düzeyinin düşük olduğu uluslararası çalışmalarda gösterilmiştir. Li ve ark. $^{32}$, infertilite tedavisi için başvuran 1192 kadının \%68.6'sının D vitamini düzeyinin yetersiz $(<32 \mathrm{ng} / \mathrm{ml}), \quad \% 22.2$ 'sinin eksik olduğunu saptamıştır. Pagliardini ve ark. ${ }^{16}$ infertilite tedavisi için başvuran 1072 kadının \%77.4'ünün D vitamini düzeyinin 30 ng/mL'nin altında olduğunu bulmuştur. Bir vaka kontrol çalışmasında, Suudi Arabistan'da 83 subfertil kadın ile 98 gebe kadının D vitamini düzeyleri karşılaştırılmış, subfertil grupta D vitamini eksikliğinin anlamlı oranda daha fazla olduğu saptanmıştır. ${ }^{33}$ Pacis ve ark.'nın ${ }^{34}$ yürüttügü sistematik incelemede Yardımcı Üreme Teknikleri (YÜT) uygulanan kadınlarda $\% 27.7$ oranında D vitamini eksikliği saptanmıştır. Başka bir sistematik derleme ve meta analiz çalışmasında YÜT uygulanan kadınlarda $D$ vitamini eksikliği, batı ülkelerinde \%21-31 arasındayken, İran çalışmalarında \%75-99 arasında olduğu saptanmıştır. ${ }^{35}$

\section{Türkiye'de D Vitamini Düzeyi}

Ülkemizde beslenme, geleneksel ya da kapalı giyim tarzı, güneş 1şınlarından yeterince faydalanamama nedenleriyle, yüksek oranda D vitamini yetersizliğinin ve eksikliğin olduğu, bu oranın bölge ve illere göre farklılık gösterdiği çalışmalarla ortaya çıkartılmıştır. Uçar ve ark. ${ }^{36}$, Ankara'daki bir hastane kayıtlarında 406 hastanın \% 72.5 'inde, Cigerli ve ark. ${ }^{37}$ İstanbul'daki bir hastane kayıtlarında, 2488 hastanın $\% 90$ 'nında ve Hekimsoy ve ark. ${ }^{38}$ Ege bölgesinde 391 bireyin \%88.7' sinde D vitamini eksikliği ya da yetersizliği tespit etmişlerdir. Ülkemizde üreme sağllğ 1 alanında D vitamini düzeyini değerlendiren çalışmaların gebelik ${ }^{39-41}$ ve doğum sonu döneme ${ }^{42,43}$ yoğunlaştı̆̆ 1 ve bu kadınların sadece \%10-20'sinde D vitamininin yeterli olduğu görülmektedir. Ayrıca ülkemizde infertilite tedavilerine başvuran kadınların D vitamini düzeylerini inceleyen bir çalışmaya ulaşılmamıştır.

$\mathrm{Bu}$ derlemenin amac1 In Vitro Fertilizasyon (IVF) tedavisi sonuçları üzerine D vitamininin etkilerini incelemek ve bu konuda farkındalık oluşturmaktır. 
Tablo 1. IVF tedavisi gören kadınların D Vitamini düzeylerinin tedavi sonuçlarına etkisini inceleyen çalışmaların dağılımı

\begin{tabular}{|c|c|c|c|c|c|c|}
\hline Yazar, Y11, & Ülke & Amaç & $\mathrm{N}$ & Fertilizasyon (\%) & İmplantasyon (\%) & Klinik Gebelik (\%) \\
\hline $\begin{array}{l}\text { Farzadi ve ark., } \\
2015(45)\end{array}$ & İran & $\begin{array}{l}\text { Foliküler sıvıdaki D vitamini düzeyi ile } \\
\text { YÜT sonuçları arasındaki ilişkinin } \\
\text { belirlenmesi }\end{array}$ & 80 & Bilgi verilmemiş & Bilgi verilmemiş & $\begin{array}{l}\text { Gebe: \% } 22.5(\mathrm{D} \\
\text { vitamini: } 15.8 \pm 4.5) \\
\text { Gebe olmayan: \% } 77.5(\mathrm{D} \\
\text { vitamini: } 11.6 \pm 5.5) ; \\
\mathbf{p = 0 . 0 0 7}\end{array}$ \\
\hline $\begin{array}{l}\text { Franasiak ve ark., } \\
2015(53)\end{array}$ & Amerika & $\begin{array}{l}\text { Blastosist transferi uygulanan kadınlarda } \\
\text { klinik gebelik ve implantasyon oranının, } \\
\text { serum D vitamini düzeyi ile ilişkisinin } \\
\text { belirlenmesi }\end{array}$ & $517 *$ & Bilgi verilmemiş & Bilgi verilmemiş & $\begin{array}{l}\text { Eksik: } \% 37.1 \\
\text { Yetersiz: } \% 51.4 \\
\text { Yeterli: } \% 11.42\end{array}$ \\
\hline $\begin{array}{l}\text { Firouzabadi ve ark., } \\
2014(55)\end{array}$ & İran & $\begin{array}{l}\text { IVF tedavisi sonuçlarina, serum ve } \\
\text { foliküler D vitamini düzeyinin etkisinin } \\
\text { belirlenmesi }\end{array}$ & 221 & $\begin{array}{l}\text { Eksik: } 43.17 \\
\text { Yetersiz: } 53.37 \\
\text { Yeterli: } 58.77 \\
\text { p }=0.054\end{array}$ & $\begin{array}{l}\text { Eksik: } 17.33 \\
\text { Yetersiz: } 15.26 \\
\text { Yeterli: } 18.75 \\
p=0.579\end{array}$ & $\begin{array}{l}\text { Eksik: \%31.1 } \\
\text { Yetersiz: \%63.5- } \\
\text { Yeterli: } \% 5.4 \\
p=0.094\end{array}$ \\
\hline $\begin{array}{l}\text { Aflatoonian ve ark., } \\
2014(54)\end{array}$ & İran & $\begin{array}{l}\text { Frozen embriyo transferinde (ET) fertilite } \\
\text { sonuçlarına, serum ve foliküler D } \\
\text { vitamininin etkisinin incelenmesi }\end{array}$ & $128 \S$ & Bilgi verilmemiş & Bilgi verilmemiş & $\begin{array}{l}\text { D vitamini tedavi grubu: } \\
\% 25.5 \\
\text { Kontrol grubu: } \% 21.80 \\
\text { p=0.81 }\end{array}$ \\
\hline $\begin{array}{l}\text { Fabris ve ark., } 2014 \\
\text { (52) }\end{array}$ & $\begin{array}{l}\text { Birleşik } \\
\text { Arap } \\
\text { Emirlikleri }\end{array}$ & $\begin{array}{l}\text { Oosit donasyonunda gebelik oranina, } \\
\text { serum D vitamini düzeyinin etkisinin } \\
\text { incelenmesi }\end{array}$ & 267 & Bilgi verilmemiş & $\begin{array}{l}\text { Eksik: } 65.2 \\
\text { Yetersiz: } 63.4 \\
\text { Yeterli: } 60.9 \\
\mathrm{p}=0.894\end{array}$ & $\begin{array}{l}\text { Eksik: } 73.9 \\
\text { Yetersiz: } 69.9- \\
\text { Yeterli: } 70.0 \\
\text { p= } 0.787\end{array}$ \\
\hline $\begin{array}{l}\text { Paffoni ve ark., } \\
2014(49)\end{array}$ & İtalya & $\begin{array}{l}\text { IVF tedavisi sonuçlarına, serum D } \\
\text { vitamini düzeyinin etkisinin belirlenmesi }\end{array}$ & $480 \dagger$ & $\begin{array}{l}\text { Eksik: } 75, \text { Yetersiz } \\
\text { ve Yeterli: } 80 \\
p=0.57\end{array}$ & $\begin{array}{l}\text { Eksik: } \% 13 \text {, } \\
\text { Yetersiz ve Yeterli: } \\
\% 21 \\
\mathbf{p = 0 . 0 0 6}\end{array}$ & $\begin{array}{l}\text { Eksik: } \% 20 \\
\text { Yetersiz ve Yeterli: } \% 31 \\
\mathbf{p = 0 . 0 2}\end{array}$ \\
\hline $\begin{array}{l}\text { Polyzos ve ark., } \\
2014(51)\end{array}$ & Belçika & $\begin{array}{l}\text { ET uygulanan kadınlarda gebelik oranına, } \\
\text { serum D vitamini düzeyinin etkisinin } \\
\text { belirlenmesi }\end{array}$ & 368 & $\begin{array}{l}\text { Eksik: } 78.7 \\
\text { Yetersiz ve Yeterli: } \\
78.2 \\
p=0.81\end{array}$ & Bilgi verilmemiş & $\begin{array}{l}\text { Eksik: } \% 41 \\
\text { Yetersiz ve Yeterli: } \% 54 \\
\mathbf{p = 0 . 0 1 5}\end{array}$ \\
\hline
\end{tabular}


Tablo 1 ( devamı) IVF tedavisi gören kadınların D Vitamini düzeylerinin tedavi sonuçlarına etkisini inceleyen çalışmaların dağılımı

\begin{tabular}{|c|c|c|c|c|c|c|}
\hline $\begin{array}{l}\text { Rudick ve ark., } \\
2014(48)\end{array}$ & Amerika & $\begin{array}{l}\text { Oosit donasyonu sonuçlarına, serum } \mathrm{D} \\
\text { vitamini düzeyinin etkisinin belirlenmesi }\end{array}$ & 99 & $\begin{array}{l}\text { Eksik: } 75.8 \pm 18.4 \\
\text { Yetersiz: } 75.3 \pm 16.5 \\
\text { Yeterli: } 76.1 \pm 12.6 \\
p=0.88\end{array}$ & Bilgi verilmemiş & $\begin{array}{l}\text { Eksik: \%35 } \\
\text { Yetersiz: } \% 42- \\
\text { Yeterli: } \% 74 \\
\mathbf{p}=\mathbf{0 . 0 0 2}\end{array}$ \\
\hline $\begin{array}{l}\text { Garbedian ve ark., } \\
2013(50)\end{array}$ & Kanada & $\begin{array}{l}\text { IVF tedavisi sonrası klinik gebelik } \\
\text { sonuçlarına, serum } \mathrm{D} \text { vitamini düzeyinin } \\
\text { etkisinin belirlenmesi }\end{array}$ & $173 t$ & Bilgi verilmemiş & $\begin{array}{l}\text { Eksik ve yetersiz: } \\
25.6 \\
\text { Yeterli: } 34.5 \\
p=0.60\end{array}$ & $\begin{array}{l}\text { Eksik ve yetersiz: \%34.7 } \\
\text { Yeterli: \% } 52.5 \\
\mathbf{p}<\mathbf{0 . 0 0 1}\end{array}$ \\
\hline $\begin{array}{l}\text { Rudick ve ark., } \\
2012(47)\end{array}$ & Amerika & $\begin{array}{l}\text { D vitamini düzeyinin IVF tedavisi } \\
\text { sonuçlarına etkisinin incelenmesi }\end{array}$ & 188 & $\begin{array}{l}\text { Eksik: } 74 \pm 17 \\
\text { Yetersiz: } 71 \pm 23 \\
\text { Yeterli: } 68 \pm 25 \\
\text { p }=0.79\end{array}$ & $\begin{array}{l}\text { Eksik: } 16 \pm 27 \\
\text { Yetersiz: } 18 \pm 27 \\
\text { Yeterli: } 19 \pm 26 \\
\text { p=0.38 }\end{array}$ & $\begin{array}{l}\text { Eksik: } \% 36 \\
\text { Yetersiz: } \% 41 \\
\text { Yeterli: } \% 43 \\
\mathrm{p}=0.48\end{array}$ \\
\hline $\begin{array}{l}\text { Aleyasin ve ark., } \\
2011(46)\end{array}$ & İran & $\begin{array}{l}\text { Foliküler sıvıdaki } 25-\mathrm{OH} \text { vitamin } \mathrm{D} \\
\text { düzeyi ile YÜT arasındaki ilişkinin } \\
\text { belirlenmesi }\end{array}$ & 82 & $\begin{array}{l}\text { Eksik: } 79 \\
\text { Yetersiz: } 67.8 \\
\text { Yeterli: } 68.3 \\
\mathrm{p}=0.274\end{array}$ & $\begin{array}{l}\text { Eksik: } 9.6 \\
\text { Yetersiz: } 13 \\
\text { Yeterli: } 15.9 \\
\text { p=0.857 }\end{array}$ & $\begin{array}{l}\text { Eksik: \%29.6 } \\
\text { Yetersiz: \%29.6- } \\
\text { Yeterli: \%33.3 } \\
\text { p=0.995 }\end{array}$ \\
\hline $\begin{array}{l}\text { Anifandis ve ark., } \\
2010(56)\end{array}$ & Yunanistan & $\begin{array}{l}\text { Foliküler sıvıdaki } 25-\mathrm{OH} \text { vitamin } \mathrm{D} \\
\text { düzeyinin YÜT sonuçlarına etkisinin } \\
\text { belirlenmesi }\end{array}$ & $101 * *$ & Bilgi verilmemiş & Bilgi verilmemiş & $\begin{array}{l}\text { Eksik: \%32.3 } \\
\text { Yetersiz: } \% 32.7 \\
\text { Yeterli: \% } 14.3 \\
\text { p=0.047 }\end{array}$ \\
\hline $\begin{array}{l}\text { Ozkan ve ark., } 2010 \\
(44)\end{array}$ & Amerika & $\begin{array}{l}\text { Foliküler sıvıdaki } 25-\mathrm{OH} \text { vitamin D } \\
\text { düzeyi ile YÜT sonuçları arasındaki } \\
\text { ilişkinin belirlenmesi }\end{array}$ & 84 & Bilgi verilmemiş & $\begin{array}{l}\text { Eksik }<\text { Yetersiz }<\text { Yete } \\
\text { rli } \\
\mathbf{p}=\mathbf{0 . 0 4 1}\end{array}$ & $\begin{array}{l}\text { Gebe: } \% 30.9 \\
\text { (D vitamini: } 34.42 \pm 15.58 \text { ) } \\
\text { Gebe olmayan: } \% 69.04 \\
\text { (D vitamini: } 25.62 \pm 10.53 \text { ) } \\
\mathbf{p}=\mathbf{0 . 0 1 3}\end{array}$ \\
\hline
\end{tabular}

* 517 kadın çalışmaya alınmış, bu kadınlardan 224’ü gebedir., † 480 kadın çalışmaya alınmasına karşın, 335 kadın ET aşamasına ulaşmıştır., $\$ 173$ kadına oosit toplama yapılmasına karşın, 162 kadına ET yapılmıştır. § 128 kadın çalışmaya alınmasına karşın, 106 kadın ET aşamasına ulaşmıştır.

**101 kadına oosit stimülasyon yapılmasına karşın, 86 kadın ET aşamasına ulaşmıştır. Kimyasal, klinik, kesin gebelik oranları dikkate alınarak, araştırmacılar tarafından klinik gebelik oranları dikkate alınarak hesaplanmıştır. 


\section{In Vitro Fertilization Sonuçları Üzerine D Vitaminin Etkileri}

Ulaşılabilen literatürde IVF sonuçları üzerine D vitamininin etkilerini inceleyen 2010-2015 yılları arasında yayınlanmış 13 çalışmaya ulaşılmıştır. ${ }^{44-56}$ Çalışmalardan sekizinde kanda, dördünde foliküler sıvıda, birinde ise hem kan hem de foliküler sıvıda ölçülen D vitamini seviyeleri ile IVF sonuçları arasındaki ilişkilere odaklandığ 1 görülmektedir. Çalışmalardan yedisi (\%53.8) yeterli D vitamini düzeyinin IVF sonuçlarını olumlu etkilediğini, beşi (\%38.5) yeterli D vitamini düzeyi ile IVF sonuçları arasında ilişki olmadığını ve biri (\%7.7) yeterli D vitamini düzeyinin IVF sonuçlarını olumsuz etkilediğini saptamıştır. Tablo 1'de IVF sonuçları üzerine D vitamini düzeyinin etkilerini inceleyen çalışmaların analizi verilmiştir.

Kandaki D vitamini ile foliküler sıvıdaki D vitamini arasındaki ilişkiyi inceleyen ilk çalışmada, IVF uygulanan 84 kadının ovarian folikül sıvılarındaki $\mathrm{D}$ vitamini düzeyi arttıkça, kandaki D vitamini düzeyinin de arttığı ve bunun gebelik oranını istatistiksel olarak arttırdığı ortaya çıkmıştır. ${ }^{44}$ Dahası tedavinin başında D vitamini düzeyi ortalama $40 \mathrm{ng} / \mathrm{ml}$ olan kadınların IVF şansını, 16ng/ml olanlara göre 4 kat daha yüksek bulmuşlardır.

Farzadi ve ark. ${ }^{45}, 80$ infertilite tedavisi gören kadında foliküler sıvıda D vitamini düzeyi ile YÜT sonuçları arasındaki ilişkiyi inceledikleri çalışmada, gebe kadınlarda foliküler sıvıdaki D vitamini düzeyi konsantrasyonun, gebe olmayan kadınlara göre anlamlı oranda yüksek olduğunu ancak oosit sayısı ve kalitesi, fertilize oosit sayısı arasında gruplar arasında fark olmadığını saptamıştır. Yine aynı çalışmada D vitamini konsantrasyonu arttıkça, implantasyon oranının da arttı $\breve{g} 1$ bulunmuştur. Aleyasin ve ark. ${ }^{46}$ foliküler sıvıda D vitamini düzeyi ile YÜT sonuçları arasındaki ilişkiyi inceledikleri çalışmada, gebe olan $(n=24)$ kadınların foliküler D vitamini düzeyi (9.19 $\mathrm{ng} / \mathrm{ml})$ ile gebe olmayan kadınların $(\mathrm{n}=53)$ $(10.34 \mathrm{ng} / \mathrm{ml})$ düzeyleri arasında fark saptamamıştır. Aynı çalışmada foliküler sıvıdaki D vitamini düzeyinin artmasıyla, fertilizasyon oranında anlamlı azalma bulunurken, implantasyon oranında değişiklik olmadığı bulunmuştur.

Kanda ölçülen D vitamini seviyeleri ile gebelik sonuçları arasındaki ilişkiyi inceleyen 10 çalışmaya ulaşılmıştır. Rudick ve ark. ${ }^{47}$, IVF tedavisi gören 188 kadın ile yaptığı araştırmada çalışma grubundaki Kafkas ve Asyalılarda D vitamini konsantrasyonunun önemli oranda yüksek olduğu, Kafkaslarda D vitamini artış1 gebelik oranıyla ilişkili bulunurken, Asyalılarda ters bir ilişki gözlenmiştir. Transfer edilen embriyo kalite ve miktarı dikkate alınarak yapılan analizlerde, yeterli $\mathrm{D}$ vitamini düzeyi olan kadınların, IVF başarı oranının 4 kez arttığı ortaya konmuştur. Kaliforniya'da farklı rrklardan 99 yumurta donasyonu uygulanan kadınla yapılan retrospektif kohort bir çalışmada, klinik gebelik oranı D vitamini eksikliği olan grupta \%37 iken, D vitamini yeterli olan grupta $\% 78$, canlı doğum oranı ise sirayla $\% 31$ ve $\% 59$ olarak bulunmuştur. ${ }^{48}$ Paffoni ve ark. ${ }^{49}$ İtalya'da, Garbedian ve ark. ${ }^{50}$ Kanada'da kinik gebelik oranı ile ilgili benzer sonuca ulaşmışlardır. Polyzos ve ark. ${ }^{(51)}$ ET uygulanan 368 kadınla yaptıkları çalışmada, D vitamini eksikliğinin bağımsız olarak kinik gebelik oranın azalması ile ilişkili olduğunu, 0.56 kat riski arttırdığını saptamıştır.

$\mathrm{Bu}$ çalışmaların aksine, $\mathrm{D}$ vitamini düzeyi ile gebelik oranları arasında ilişki olmadığını gösteren birkaç çalışmaya ulaşılmıştır. Fabris ve ark. ${ }^{52}, 267$ yumurta donasyonu uygulanan kadınla yaptığ 1 retrospektif kohort bir çalışmada, D vitamini düzeyi normal olan grup ile yetersiz ve eksik olan kadınların implantasyon (sirasiyla \%60.9, \%63.4 ve $\% 65.2$ ) ve gebelik (sirasiyla \%70, \%69.9, \%73.9) oranları arasında fark bulmamıştır. Franasiak ve ark. ${ }^{53}$ retrospektif ve kohort düzende 517 ET uygulanan kadının D vitamini düzeyi ile gebelik sonuçları arasında ilişki bulunmadığını bildirmişlerdir. Aflatoonian ve ark. $^{54}$, frozen ET uygulamasında D vitamini yetersizliği tedavisinin fertilite sonuçlarına etkisi olup olmadığını incelemişlerdir. $\mathrm{Bu}$ çalışmada D vitamini yetersiz olan 57 kadına 68 hafta süresince haftalık 50000 IU D vitamini destek tedavisi uygulanmış, 57 kadına ise hiçbir tedavi uygulanmamış ve ET sonrasında gruplar arasında gebelik oranlarında anlamlı fark saptanmamıştır. Firouzabadi ve ark. ${ }^{55}$, infertilite tedavisi gören 221 kadının ovarian folikül sıvısı ve kan D vitamini konsantrasyonunu çalışmışlardır. D vitamini eksikliği, yetersizliği ve yeterliliği açısından kadınlar gruplandırılmış, fertilizasyon ve implantasyon oranları açısından gruplar arasında fark olmadığı bulunmuştur. Dahas1, Anifandis ve ark. ${ }^{(56)}, 101$ IVF tedavisi gören kadının folikül sıvısında D vitamini ve glukoz seviyelerini incelemiş, D vitamini artışının düşük embriyo kalitesi ve gebelik oranı ile ilişkili olduğunu bulmuştur. 
Literatürde maliyet analizleri sonucunda YÜT öncesi D vitamini ölçümü ve desteğinin maliyet-etkin olabileceği gösterilmiştir. Yine de D vitamini ve IVF sonuçlarına ilişkin kanıt düzeyi 1 ve öneri düzeyi A olan kanıt eksikliği nedeniyle rutin olarak IVF tedavisi öncesi ve/veya surasinda D vitamini destek tedavisinin açısından tam bir öneri getirilemediği, hekimin görüşüne bırakıldı ğ1 görülmektedir. ${ }^{11,34}$ Uluslararası rehberlerde D vitamini $<10 \mathrm{ng} / \mathrm{mL}$ altında olduğunda bir kez depo 50.000 İU, sonra günlük 800-1000 İU idame doz, $10-20 \mathrm{ng} / \mathrm{mL}$ arasindaysa genelde 3 ay süren günlük 800-1000 İU idame doz, 20-30 $\mathrm{ng} / \mathrm{mL}$ arasında ise günlük 600-800 İU D vitamini desteği verilmesi önerilmektedir. ${ }^{(57)}$ Kadın sağlığı ve IVF sonuçları üzerine D vitaminin potansiyel olumlu etkileri göz önünde bulundurulduğunda, D vitaminine ilişkin sağlık bakım profesyonellerinin farkındalığını arttırmanın önemli olduğu düşünülmektedir.

\section{Sonuç}

$\mathrm{Bu}$ literatür incelemesinde ulaşılan çalışmaların yarısı D vitamini eksikliğinin olumsuz IVF sonuçları ve parametreleri ile ilişkili olduğuna odaklanmıştır. Ancak bu çalışmalarda bazı istatistiksel eksiklikleri olduğu saptanmıştır. D vitamini eksikliği ile IVF sonuçları arasında ilişki olmadığını saptayan araştırmalarda IVF sonuçları açısından D vitamini eksikliğinin karıştırıcı bir faktör olabileceği ileri sürülmüştür. Sonuç olarak D vitamini ve IVF sonuçları arasındaki ilişkiyi ortaya koyacak büyük ölçekli, kohort ve RKÇ’lara ihtiyaç olduğu görülmektedir.

Ülkemiz için IVF tedavisi gören kadınların D vitamini düzeylerini ortaya koyacak tanımlayıcı çalışmalara ihtiyaç olduğu açıktır. Gebelik ve doğum sonu dönemdeki kadınlardaki D vitamini seviyeleri göz önünde bulundurulduğunda, IVF tedavisi gören kadınların da $\mathrm{D}$ vitaminlerinin düşük olacağı öngörülmektedir. Dahası ülkemiz ölçeğinde D vitamini ve IVF sonuçları arasındaki ilişkinin incelenmesi önerilebilir. Ülkemizde IVF tedavilerinde rutin olarak D vitamini takibi yapılamamaktadır. Yapılacak çalışmalarla rutin D vitamini izlemine gerek olup olmadığ 1 açıklığa kavuşacaktır.

\section{Kaynaklar}

1. Oberhelman SS, Thacher TD. Vitamin D deficiency in the 21st century: an overview. eds. Watson RR. Handbook of Vitamin D in
Human Health. Netherlands: Wageningen Academic Publishers, 2013. p:13-37.

2. Fidan F, Alkan BM, Tosun A. Çağın pandemisi: D vitamini eksikliği ve yetersizliği [Pandemic Era: Vitamin D Deficiency and Insufficiency]. Türk Osteoporoz Dergisi [Turkish Journal of Osteoporosis] 2014; 20: 71-4.

3. Weggemans RM, Schaafsma G, Kromhout D. Towards an adequate intake of vitamin D. An advisory report of the Health Council of the Netherlands. Eur J Clin Nutr 2009;63(12): 1455-7.

4. Özkan B, Döneray H. D vitamininin iskelet sistemi dışı etkileri [The non-skeletal effects of vitamin D] Çocuk Sağlığı ve Hastalıkları Dergisi [Journal of Child Health and Diseases] 2011; 54: 99-119.

5. Down J, Stafford D. The Vitamin D Cure Revised Edition. Canada: John Wiley \& Sons. 2012. p:117-78.

6. Kıdır V. D Vitamininin kardiyovasküler ve metabolik etkileri [Cardiovascular and metabolic effects of vitamin D]. Klinik ve Deneysel Araştırmalar Dergisi [Journal of Clinical and Experimental Investigations] 2013; 4 (3): 398-404.

7. Lauretani F, Maggio M, Ruggiero C, Ceda GP, Ferrucci L. Vitamin D in health of seniors. eds. Watson RR. Handbook of Vitamin D in Human Health. Netherlands: Wageningen Academic Publishers, 2013. p:39-51.

8. Grzechocinska B, Dabrowski FA, Cyganek A, Wielgos M. The role of vitamin D in impaired fertility treatment. Neuro Endocrinol Lett 2013; 34(8): 756-62.

9. De-Regil LM, Palacios C, Lombardo LK, Peña-Rosas JP. Vitamin D supplementation for women during pregnancy. Cochrane Database Syst Rev. 12 (1), Art. No: CD008873. DOI: 10.1002/14651858.CD008873.pub3.

10. Colonese F, Laganà AS, Colonese E, Sofo V, Salmeri FM, Granese R, et al. The pleiotropic effects of vitamin D in gynaecological and obstetric diseases: an overview on a hot topic. Biomed Res Int. 2015; 2015: 1-11.

11. Lerchbaum E, Obermayer-Pietsch B. Vitamin D and fertility: A systematic review. Eur J Endocrinol 2012; 166: 765-78.

12. Lerchbaum E, Rabe T. Vitamin D and female fertility. Curr Opin Obstet Gynecol 2014; 26: 145-50.

13. Ferrero S, Gillott DJ, Anserini P, Remorgida V, Price KM, Ragni N, et al. Vitamin D binding protein in endometriosis. Soc Gynecol Investig 2005; 12: 272-7.

14. Somigliana E, Panina-Bordignon P, Murone S, Di Lucia P, Vercellini P, Vigano P. Vitamin D reserve is higher in women with endometriosis. Hum Reprod 2007; 22: 2273-78. 
15. Harris H, Chavarro J, Malspeis S, Willett WC, Missmer SA. Dairy-food, calcium, magnesium, and vitamin D intake and endometriosis: a prospective cohort study. Am J Epidemiol 2013; 177: 420-30.

16. Pagliardini L, Vigano' P, Molgora M, Persico $\mathrm{P}$, Salonia A, Vailati SH, et al. High prevalence of vitamin $\mathrm{d}$ deficiency in infertile women referring for assisted reproduction. Nutrients 2015; 7: 9972-84.

17. Sur D, Chakravorty R. The Relationship between Vitamin $\mathrm{D}$, insulin resistance and infertility in PCOS women. Gynecol Obstet 2015; 5:1-4.

18. Wehr E, Pieber TR, Obermayer-Pietsch B. Effect of vitamin D3 treatment on glucose metabolism and menstrual frequency in polycystic ovary syndrome women: A pilot study. J Endocrinol Invest 2011; 34: 757-63.

19. Thomson RL, Spedding S, Buckley JD. Vitamin D in the aetiology and management of polycystic ovary syndrome. Clin Endocrinol 2012; 77: 343-50.

20. Asadi M, Matin N, Frootan M, Mohamadpour J, Qorbani M, Tanha FD. Vitamin D improves endometrial thickness in PCOS women who need intrauterine insemination: A randomized double-blind placebo. Arch Gynecol Obstet 2014; 289: 865-70.

21. Baird DD, Hill MC, Schectman JM, Hollis BW. Vitamin D and the risk of uterine fibroids. Epidemiology 2013; 24: 447-53.

22. Paffoni A, Somigliana E, Vigano' P, Benaglia L, Cardellicchio L, Pagliardini L, et al. Vitamin D status in women with uterine leiomyomas. J Clin Endocrinol Metab 2013: 98(8): E1374-78.

23. Sabry M, Halder SK, Allah AS, Roshdy E, Rajaratnam V, Al-Hendy A. Serum vitamin D3 level inversely correlates with uterine fibroid volume in different ethnic groups: a crosssectional observational study. Int $\mathrm{J}$ Womens Health 2013; 5: 93-100.

24. Blomberg Jensen M, Bjerrum PJ, Jessen TE, Nielsen JE, Joensen UN, Olesen IA, et al. Vitamin D is positively associated with sperm motility and increases intracellular calcium in human spermatozoa. Hum Reprod 2011; 26: 1307-17.

25. Hammoud AO, Meikle AW, Peterson CM, Stanford J, Gibson M, Carrell DT. Association of 25-hydroxy-vitamin D levels with semen and hormonal parameters. Asian J Androl 2012; 14: 855-9.

26. Wehr E, Pilz S, Boehm BO, März W, Obermayer-Pietsch B. Association of vitamin D status with serum androgen levels in men. Clin Endocrinol 2010; 73: 243-8.

27. Pilz S, Frisch S, Koertke H, Kuhn J, Dreier J, Obermayer-Pietsch B, et al. Effect of vitamin D supplementation on testosterone levels in men. Horm Metab Res 2011; 43: 223-5.

28. Merhi Z, Doswell A, Krebs K, Cipolla M. Vitamin D alters genes involved in follicular development and steroidogenesis in human cumulus granulosa cells. J Clin Endocrinol Metab 2014; 99(6): E1137-45.

29. Abdul-Rasheed OF, Ali NM, Abdulrasul EA. Serum vitamin $\mathrm{D}$ and anti-mullerian hormone levels in Iraqi infertile women at Baghdad city. International Journal of Basic and Applied Sciences 2015; 4(4):375-80.

30. Kebapcilar AG, Kulaksizoglu M, Kebapcilar L, Gonen MS, Unlü A, Topcu A, et al., Is there a link between premature ovarian failure and serum concentrations of vitamin D, zinc, and copper? Menopause 2013; 20: 94-9.

31. Luk J, Torrealday S, Perry NG, Pal L. Relevance of vitamin D in reproduction. Hum Reprod 2012; 27(10): 3015-27.

32. Li L, Schriock E, Dougall K, Givens C. Prevalence and risk factors of vitamin D deficiency in women with infertility. Fertil Steril 2012; 97(3): S26.

33. Al-Jaroudi D, Al-Banyan N, Aljohani NJ, Kaddour O, Al-Tannir M. Vitamin D deficiency among subfertile women: casecontrol study. Gynecological Endocrinology 2015; 11: 1-4.

34. Pacis MM, Fortin CN, Zarek SM, Mumford SL, Segars JH. Vitamin D and assisted reproduction: Should vitamin D be routinely screened and repleted prior to ART? A systematic review. J Assist Reprod Genet 2015; 32(3):323-5.

35. Vanni VS, Vigano P, Somigliana E, Papaleo E, Paffoni A, Pagliardini L, et al. Vitamin D and assisted reproduction technologies: Current concepts. Reprod Biol Endocrinol 2014; 12: 47.

36. Uçar F, Yavuz Taşlıpınar M. Özden Soydaş A, Özcan N. Ankara Etlik İhtisas Eğitim Ve Araştırma Hastanesine başvuran hastalarda 25$\mathrm{OH}$ Vitamin D düzeyleri [25-OH Vitamin D levels in patients admitted to Ankara Etlik İhtisas Training and Research Hospital] . Eur J Basic Med Sci [Avrupa Temel Tip Bilimleri Dergisi] 2012; 2(1):12-5.

37. Cigerli Ö, Parildar H, Unal AD, Tarcin Ö. Erdal R, Guvener Demirag N. Vitamin D deficiency is a problem for adult out patients? A university hospital sample in Istanbul, Turkey. Public Health Nutr 2012; 16(7): 1306-13.

38. Hekimsoy Z, Dinç G, Kafesçiler S, Onur E, Güvenç Y, Pala T, et al. Vitamin D status among adults in the Aegean region of Turkey. BMC Public Health 2010; 10(782): 1-7.

39. Erol M, İşman FK, Kucur M, Hacıbekiroğlu M. Annede D vitamini eksikliğinin değerlendirilmesi [Evalution of maternal 
vitamin D deficiency]. Türk Pediatri Arşivi [Turkish Archives of Pediatrics] 2007; 42(1): 29-32.

40. Halicioglu O, Aksit S, Koc F, Akman SA, Albudak E, Yaprak I, et al. Vitamin D deficiency in pregnant women and their neonates in spring time in western Turkey. Paediatric and Perinatal Epidemiology. 2012; 23(1): 53-60.

41. Aydoğmuş S, Kelekçi S, Aydoğmuş H, Eriş S, Descidioğlu R, Yılmaz B, et al. High prevalence of vitamin $\mathrm{D}$ deficiency among pregnant women in a Turkish population and impact on perinatal outcomes. J Matern Fetal Neonatal Med 2015; 28 (15): 1828-32.

42. Ergül TA, Berberoğlu M, Atasay B, Şıklar Z, Bilir P, Arsan S, et al. Vitamin D deficiency in Turkish mothers and their neonates and in women of reproductive age. J Clin Res Ped Endo. 2009; 1(6): 266-9.

43. Gür EB, Turan GA, Tatar S, Gökduman A, Karadeniz M, Çelik G, et al. The effect of place of residence and lifestyle on vitamin D deficiency in pregnancy: Comparison of eastern and western parts of Turkey. J Turk Ger Gynecol Assoc 2014; 15: 149-155.

44. Ozkan S, Jindal S, Greenseid K, Shu J, Zeitlian $\mathrm{G}$, Hickmon C, et al. Replete vitamin D stores predict reproductive success following in vitro fertilization. Fertil Steril 2010; 94(4): 1314-9.

45. Farzadi L, Khayatzadeh Bidgoli H, Ghojazadeh M, Bahrami Z, Fattahi A, Latifi $\mathrm{Z}$, et al. Correlation between follicular fluid 25$\mathrm{OH}$ vitamin $\mathrm{D}$ and assisted reproductive outcomes. Iran J Reprod Med 2015; 13(6): 3616.

46. Aleyasin A, Hosseini MA, Mahdavi A, Safdarian L, Fallahi P, Mohajeri MR, et al. Predictive value of the level of vitamin D in follicular fluid on the outcome of assisted reproductive technology. Eur J Obstet Gynecol Reprod Biol 2011; 159(1): 132-7.

47. Rudick BJ, Ingles S, Chung K, Stanczyk F, Paulson R, Bendikson K. Characterizing the influence of vitamin D levels on IVF outcomes. Hum Reprod 2012; 27(11): 3321-7.

48. Rudick, BJ, Ingles SA, Chung K, Stanczyk FZ, Paulson RJ, Bendikson KA. Influence of vitamin $\mathrm{D}$ levels on in vitro fertilization outcomes in donor-recipient cycles. Fertil Steril. 2014; 101: 447-52.

49. Paffoni A, Ferrari S, Vigano P, Pagliardini L, Papaleo E, Candiani M, et al. Vitamin D deficiency and infertility: Insights from in vitro fertilization cycles. J Clin Endocrinol Metab 2014; 99: E2372-6.

50. Garbedian K, Boggild M, Moody J, Liu KE. Effect of vitamin D status on clinical pregnancy rates following in vitro fertilization. CMAJ Open 2013; 1: E77-82.
51. Polyzos NP, Anckaert E, Guzman L, Schiettecatte J, Van Landuyt L, Camus M, et al. Vitamin D deficiency and pregnancy rates in women undergoing single embryo, blastocyst stage, transfer (SET) for IVF/ ICSI. Hum Reprod 2014; 29(9): 2032-40.

52. Fabris A, Pacheco A, Cruz M, Puente JM, Fatemi H, Garcia-Velasco JA. Impact of circulating levels of total and bioavailable serum vitamin $\mathrm{D}$ on pregnancy rate in egg donation recipients. Fertil Steril 2014; 102(6): 1608-12.

53. Franasiak JM, Molinaro TA, Dubell EK, Scott KL, Ruiz AR, Forman EJ, et al. Vitamin D levels do not affect IVF outcomes following the transfer of euploid blastocysts. Am J Obstet Gynecol 2015; 212 (3): 315.e1-6

54. Aflatoonian A, Arabjahvani F, Eftekhar M. Sayadi M. Effect of vitamin D insufficiency treatment on fertility outcomes in frozenthawed embryo transfer cycles: A randomized clinical trial. Iran J Reprod Med Vol 2014; 12(9): 595-600.

55. Firouzabadi RD, Rahmani E, Rahsepar M, Firouzabadi MM. Value of follicular fluid vitamin $\mathrm{D}$ in predicting the pregnancy rate in an IVF program. Arch Gynecol Obstet 2014; 289(1): 201-6.

56. Anifandis GM, Dafopoulos K, Messini CI, Chalvatzas N, Liakos N, Pournaras S, et al. Prognostic value of follicular fluid $25-\mathrm{OH}$ vitamin $D$ and glucose levels in the IVF outcome. Reprod Biol Endocrinol 2010; 8: 91.

57. Dawson-Hughes B. Vitamin D deficiency in adults: Definition, clinical manifestations, and treatment. eds. Drezner MK, Rosen CJ, Mulder JE. UpToDate. Waltham, MA: UpToDate, 2015. 